\title{
Happy Birthday to Professor U. Grigull
}

It is our honor and pleasure to extend best wishes to Professor Grigull on the occasion of his sixtieth birthday. We do this in the name especially of his American colleagues on whom his research in the field of heat and mass transfer has made an important and lasting impression.

We will not attempt to cover in this greeting the many important contributions made by him up to the present time. These contributions are well known to members of the international heat transfer community and are treated in detail elsewhere in this volume. Rather, we would like to call to your attention the significant efforts he has made to emphasize the truly international character of heat transfer research.

Professor Grigull was one of the founding editors of the International Journal of Heat and Mass Transfer. He has served as Chairman of the Board of Editors of the Journal and is still an active member of the Board. He was a delegate from the Federal Republic of Germany during the formation of the International Assembly of Heat Transfer Conferences and is at present the President of the Assembly. In addition, he was co-chairman, with Professor E. A. Brun, of the 4th International Heat Transfer Conference held in Paris in 1970.

Professor Grigull was active in the formation of the International Centre of Heat and Mass Transfer in Belgrade, Yugoslavia, and has been vigorous in his support of the Centre as a member of its Scientific Council.

Finally, his Institute for Thermodynamics at the Technical University in Munich has been a gathering place for both mature scientists and students from all over the world and many of us have had the pleasure and profit of working with him and his colleagues in Munich.

We salute Professor Grigull for his many technical accomplishments and for his contributions to international understanding. We sincerely wish him continued success in the years ahead.
J. P. Hartnett (Chicago)

T. F. Irvine (New York) 